heightened clinical awareness that certain diseases may be related to unrecognised infection with HIV-I. Compared with data for 1984, McCormick found an excess of 295 deaths in 1989 from 11 specified causes (which included deaths from pneumonia, specific neoplasms, and external causes) in men aged 15-54 in England and Wales (p 1365). ${ }^{13}$ She estimated that if these 295 were infected with HIV-I then in only $40 \%$ had the infections been diagnosed. Doctors should therefore consider underlying HIV-I infection in any young or middle aged man in whom either pneumonia or certain malignant neoplasms have been diagnosed.

The information provided by the surveillance of cases of AIDS is important for the primary prevention of this fatal disease. Moreover, earmarked funds for direct treatment and care are allocated in proportion to the number of people with

1 Centers for Disease Control. Revision of the CDC surveillance case definition for acquired immunodeficiency syndrome. $M M W R$ 1987;36(15):1-15S

2 Working Group. Report to the director of the Public Health Laboratory Service: acquired immune deficiency syndrome in England and Wales to end 1993-projections using data to end September 1989 (Day report). Communicable Disease Report 1990 January:1-12.

3 Working Group convened by Chief Medical Officer. Acquired immune deficiency syndrome in Scotland - projections to the end of 1993 (McClelland report). Edinburgh: HMSO 1990.

Public Health Laboratory Service AIDS Centre. The surveillance of HIV-1 infection and AIDS in England and Wales. Communicable Disease Report 1991;1:R51-6.

5 Duff C, Hutchby JP. Surveillance of AIDS cases: how acceptable are the figures? $B M F$ 1988;297:965.

6 Bobby JJ, Spencer PD, Wyatt JC, Farmer RDT. AIDS deaths in the UK-how complete are the figures? Public Health 1988;102:519-24.

McCormick A. Trends in mortality statistics in England and Wales with particular reference to AIDS from 1984 to April 1987. BMY 1988;296:1289-92.
AIDS $^{14}$ - the chief medical officer has stated that underreporting could lead to the inappropriate allocation of resources, ultimately compromising the care of patients. ${ }^{15}$ As the epidemic of AIDS intensifies doctors should guard against "reporting fatigue" and continue to report cases of AIDS promptly.

BARRY G EVANS Consultant Epidemiologist

O NOEL GILL

Public Health Laboratory Service AIDS Centre, Consultant Epidemiologist

Communicable Disease Surveillance Centre,

Colindale, London NW9 5EQ

Communicable Diseases (Scotland) Unit,

JOHN A N EMSLIE Consultant Epidemiologist

Ruchill Hospital, Glasgow G20 9NB

8 McCormick A. Estimating the size of the HIV epidemic by using mortality data. Philos Trans $R$ Soc Lond [Biol] 1989;325:163-73.

9 Clarkson JA, Fine PEM. The efficiency of measles and pertussis notification in England and Wales. Int $f$ Epidemiol 1985; 14: 153-68.

10 Cox DR, Medley GF. A process of events with notification delay and the forecasting of AIDS. Philos Trans R Soc Lond [Biol] 1989;325:135-45.

11 McCormick A. Excess mortality associated with HIV epidemic in England and Wales. BMf 1991;302:1375-6.

12 Hickman M, Aldous J, Porter J, Durman L. HIV surveillance: the value of audit. $B M f$ 1991;302:1376-7

13 McCormick A. Unrecognised HIV related deaths. BMF 1991;302:1365-7.

14 NHS Management Executive. HIV and AIDS: resource allocation 1991/2. London: Department of Health, 1991. EL(91)52.

15 Department of Health. Voluntary confidential reporting of AIDS cases and deaths in HIV infected persons. London: $\mathrm{DoH}, 1990$. (PL/CMO(90)4.)

\title{
Who decides for those who can't?
}

\section{The Law Commission wants advice on making decisions for the mentally handicapped}

Recent cases on the sterilisation of mentally handicapped women have revealed a yawning gap in the law. ${ }^{1}$ In England and Wales, at least when it comes to medical decisions, no one-not relatives, doctors, or even the court - has the legal power to take a decision on treatment when the patient is mentally incompetent. As the sterilisation cases showed, the court's powers are limited to declaring that in the circumstances of the individual cases the doctors carrying out the operation would not be acting unlawfully.

The law on all types of decision making for mentally incompetent adults is outdated, fragmented, and full of holes. Canada, the United States, Australia, and many western European countries have overhauled this aspect of the law. In Britain both the Law Commission, the official law reform body for England and Wales, and its Scottish counterpart are formulating proposals for reform. In some aspects of life - for instance, decisions on accommodation or relationships - there are no legal procedures at all. In others the law operates so unsatisfactorily that it is ignored or rarely used. "As a consequence," the commission says, "the decision making process is largely unregulated and is open to exploitation and abuse. At times decisions which need to be made may not be made at all, or may be made too late. If this is so the law is frequently failing the very people it is intended to help and protect."'

The law fails not only mentally handicapped and mentally ill people but also those brain damaged by accident or with degenerative brain disorders such as Alzheimer's disease. Firstly, as the commission points out, it fails to address the problem of what tests should be used to decide whether a person is or is not capable of taking a particular decision. Many mentally impaired people will be able to take some decisions for themselves, but the way doctors decide capacity needs looking at, the commission suggests.
The absence of any mechanisms for appointing a substitute to take decisions on treatment stems from a move towards more autonomy for the mentally impaired in the early 1980 s. Under the Mental Health Act 1959 a local authority or private individual could be appointed guardian, with the powers of a parent, including the right to consent to treatment. But under the 1983 act, which replaced it, guardians can be appointed only for specific categories of mentally impaired patients and have no right to consent to treatment on their behalf.

What should be done? The commission is canvassing a wide range of options, on which it wants the views of doctors and others concerned in the care of mentally incapacitated people. ${ }^{2}$ Advance directives would help ensure that those who once had the capacity to take decisions but lose it-sufferers from senile dementia or those brain damaged by accident, for example-are treated as they would have wished. As in the United States, people could make living wills, declaring whether or not they wanted life prolonging measures used if there was no hope of recovery. Enduring powers of attorney, which allow a capable person to appoint a proxy to manage his or her financial affairs in the event of incapacity, could be extended to medical decisions.

A statute could be enacted laying down a procedure for obtaining a substitute consent to treatment. A precedent already exists in the Mental Health Act, which requires independent second opinions before psychosurgery or surgical implantation of hormones to control the male sex drive can be carried out. MENCAP has proposed a scheme under which decisions would be taken by the patient's most appropriate relative together with the doctor proposing the treatment. ${ }^{3}$ In the event of disagreement the case would be referred to a multidisciplinary local ethics committee, which would also take decisions on particularly serious treatment in accordance 
with guidelines. A joint report from two BMA committees has suggested a similar committee for each health district with legal authority to act on behalf of mentally incapacitated adults. ${ }^{+}$Decisions on minor treatment would be left to doctors and carers. The existing guardianship framework could be reformed to allow a guardian to consent to medical treatment provided the patient did not object. A more radical solution, increasingly popular in other countries, is a more flexible guardianship scheme, based on a court or tribunal. The new institution might have the power to deal with legal and financial, as well as personal, affairs, replacing the Court of Protection.

Present laws pose other difficulties for mentally handicapped people and their carers, as Gunn points out in a new edition of Sex and the Law, a guide for care staff. ${ }^{5}$ Laws designed to protect the mentally impaired from exploitation may make it difficult for them to fulfil their sexual needs and engage in non-exploitive sexual relationships. For instance, care staff who help couples to have sexual intercourse could face prosecution for aiding and abetting a criminal offence. Perhaps this is something the Law Commission could take on board as well.

Legal correspondent, $B M \mathcal{F}$

CLARE DYER

1 In particular Re F [1990] 2 Appeal Cases 1 .

2 Law Commission. Mentally incapacitated adults and decision making: an overview. London: HMSO, 991. (Consultation paper No 119.)

Royal Society for Mentally Handicapped Children and Adults (MENCAP) Working Party on the Legal, Medical, and Ethical Issues of Mental Handicap. Competence and consent to medical treatment. London: MENCAP, 1989.

4 BMA Medical Ethics Committee and Mental Health Committee. Proposals for the establishment of a decision making procedure on behalf of the mentally incapable. London: BMA, 1991.

Gunn MJ. Sex and the law: a brief guide for staff working with people with learning difficulties. 3rd ed. London: Family Planning Association, 1991.

\section{Cardiomyoplasty}

\section{Putting muscle into heart failure}

The idea of using skeletal muscle to augment the failing heart is at least 50 years old. ${ }^{12}$ Renewed enthusiasm for this idea is based on interesting new developments. These include the understanding of muscle transformation ${ }^{34}$ and the finding that skeletal muscle, if stimulated by pacing in a specific manner, can be made to act as cardiac muscle, with rhythmic contraction that is resistant to fatigue..$^{5-7}$ This process of muscle transformation involves alterations in the three major subcellular systems of muscle. The metabolic system becomes up regulated from a primary anaerobic (glycolytic) type of metabolism to an aerobic (oxidative) system. ${ }^{89}$ The calcium regulatory system becomes down regulated, with expression of a slow $\mathrm{Ca}^{2+}$ ATPase, ${ }^{10}$ while the contractile system undergoes shifts of its myosin isoforms from type 2 or "fast" fibres to type 1 or "slow" fibres, which are virtually indistinguishable from the $\beta$ myosin isoforms of cardiac muscle. ${ }^{11-13}$

At the fourth world symposium on transformed skeletal muscle for cardiac assist (Palm Springs, October 1990) it was reported that over 100 patients worldwide have undergone the operation of "cardiomyoplasty." In this procedure the latissimus dorsi muscle, with its neurovascular bundle intact, is transposed to form a wrap around the heart either to reinforce the myocardium or to substitute for a damaged area. ${ }^{1416}$

After the muscle is mobilised it is connected by electrodes, placed in the muscle close to the branches of the thoracodorsal nerve, to a pulse generator, whose timing is triggered by impulses from a myocardial sensing electrode. The pulse generator delivers a short burst of five impulses to the latissimus dorsi muscle at the onset of cardiac systole, the burst lasting $240 \mathrm{~ms}$. This is long enough to recruit the muscle into a sustained contraction and short enough to allow the muscle to relax before the next cardiac cycle. Some six to eight weeks, which includes a "vascular delay" when the muscle recovers from the effects of manipulation and is transformed by electrical stimulation, is currently required before the muscle is able to act as a biological assist device.

Most patients undergoing the procedure have had an ischaemic or dilated cardiomyopathy and have been classified as being in New York Heart Association's functional class III or, intermittently, in class IV. Most groups operating on these patients have found that, though subjective improvement is common and remarkable, objective haemodynamic evidence of improved cardiac function is much more difficult to obtain. Exceptionally, a series of 15 patients with dilated cardiomyopathy reported on in Brazil have shown significant improvement in cardiac output and concomitant reduction in pulmonary capillary pressure on exercise. ${ }^{17}$ Several centres in Europe and America are currently taking part in studies that will enable us to evaluate this potentially very useful procedure.

Research Registrar,

RUSSELL W J MILLNER

Department of Cardiothoracic Surgery,

St George's Hospital,

London SW17 0QT

JOHN R PEPPER

Senior Lecturer,

Royal Brompton National Heart Hospital,

London SW3 9HP

1 Beck CS. The development of a new blood supply to the heart by operation. Ann Surg 1935;102:801-13.

2 Leriche R, Fontaine R. Essai experimental de traitment de certains infarctus du myocard et de l'aneuvrisme du coeur par une greffe de muscle strie. Bulletin et Memoires de la Societé National de Chirurgie 1933;59:229-32.

3 Salmons S, Vrbova G. The influence of activity on some contractile characteristics of mammalian fast and slow muscle. F Physiol 1969;201:535-49.

4 Salmons S, Henriksson J. The adaptive response of skeletal muscle to increased use. Muscle Nero 1981;4:94-105.

5 Salmons S, Sreter FA. Significance of impulse activity in the transformation of skeletal muscle type. Nature 1976;263:30-4.

6 Macoviak JA, Stephenson LW, Armenti F, et al. Electrical conditioning of in situ skeletal muscle for replacement of myocardium. I Surg Res 1982;32:429-39.

7 Acker MA, Hammond RL, Mannion JD, Salmons S, Stephenson LW. An autologous biologic pump motor. I Thorac Cardiovasc Surg 1986;92:733-46.

8 Heilig A, Pette D. Changes induced in the enzyme activity pattern by electrical stimulation of fast twitch muscle. In: Pette D, ed. Plasticity of muscle. Berlin: Walter de Gryter, 1980:409-20.

9 Henrikkson J, Chi MMY, Hintz CS, et al. Chronic stimulation of mammalian muscle; changes in enzymes of six metabolic pathways. Am F Physiol 1986;251:C614-32.

10 Leberer E, Hartner KT, Brandl CJ, et al. Slow/cardiac sarcoplasmic reticulum Ca + +ATPase and phospholamban mRNAs are expressed in chronically stimulated rabbit fast-twitch muscle. Eurf Biochem 1989;185:51-4

11 Sreter FA, Gergely J, Salmons S, Romanul F. Synthesis by fast muscle of myosin light chains characteristic of slow muscle in response to long term stimulation. Nature New Biology 1973;241:17-9.

12 Bar A, Simoneau J, Pette D. Altered expression of myosin light chain isoforms in chronically stimulated fast twitch muscle of the rat. Eur f Biochem 1989;178:591-4.

13 Kirschbaum BJ, Simoneau JA, Bar A, Barton PJR, Buckingham ME, Pette D. Chronic stimulation-induced changes of myosin light chains at the mRNA and protein levels in rat fasttwitch muscle. Eur f Biochem 1989;179:232-9.

14 Carpentier A, Chachques JC. Myocardial substitution with a stimulated skeletal muscle; first successful clinical case. Lancet 1985;ii: 1267 .

15 Moreira LFP, Chagas ACP, Canaravo GP, et al. Cardiomyoplasty benefits in myocardial dysfunction. Journal of Cardiac Surgery 1989;4:164-70.

16 Magovern GJ, Heckler FR, Park SB, et al. Paced latissimus dorsi muscle used for dynamic cardiomyoplasty of left ventricular aneurysm. Ann Thorac Surg 1987;44:379-88.

17 Moreira LFP, Stolf NAG, Bocchi EA, et al. Latissimus dorsi cardiomyoplasty in the treatment of patients with dilated cardiomyopathy. Circulation 1990;82(suppl IV):257-63. 